Brooklyn Law School

BrooklynWorks

Faculty Scholarship

Fall 2019

Clinical Legal Education and the Replication of Hierarchy

Minna J. Kotkin

Follow this and additional works at: https://brooklynworks.brooklaw.edu/faculty

Part of the Legal Education Commons 


\title{
CLINICAL LEGAL EDUCATION AND THE REPLICATION OF HIERARCHY
}

\author{
MinNA J. KOTKIN*
}

It was the best of times, it was the worst of times, it was the age of wisdom, it was the age of foolishness, it was the epoch of belief, it was the epoch of incredulity, ...

Charles Dickens, A Tale of Two Cities

Trite as they may be, no words could better describe the state of clinical legal education today in the United States. Let us consider first "the best." Since the 2008 recession, both the legal and law school marketplace have experienced a marked decline in demand, resulting in sea changes in those institutions. Most experts now agree that there is no going back; these declines represent the "new normal." As a matter of economy, law firms want "practice ready" graduates. Taken together with the more general attempt to make law school more attractive to qualified undergraduates, the siren call of every law school today is "experiential learning." What clinicians have been touting for the last 40 years has finally taken root with a vengeance. There is not a law school in the country that does not give pride of place to its clinical offerings in its marketing efforts. And indeed, this is more than fluff. Law schools have vastly expanded inhouse clinical programs, externship opportunities, and course offerings that integrate some element of experiential learning through simulations or practicums. It is fair to say that few law students graduate today without a good dose of experiential education. ${ }^{1}$

But what about "the worst"? This article explores two major unintended consequences or perhaps more accurately, aspects of collateral damage, resulting from the triumph of clinical education. The damage relates to the replication of hierarchy, both in the structure of the academy, and in the provision of legal services. First, in order to meet the demand for experiential learning and to secure their status

* Professor of Law and Director, Employment Law Clinic, Brooklyn Law School. For the title of this essay, a hat tip to Duncan Kennedy, Legal Education and the Reproduction of Hierarchy, 32 J. LeGAL ED. 591 (1982).

1 In fact, in 2015, the ABA adopted Accreditation Standard 303(a), which provides: "A law school shall offer a curriculum that requires each student to satisfactorily complete at least the following: .... (3) one or more experiential course(s) totaling at least six credit hours." American Bar Association Section of Legal Educ. \& Admissions to the Bar, Standards and Rules of Procedure for Approval of Law Schools 20182019. 
and rank, the first generation of clinical teachers, who have been integrated to some degree into the academy, encouraged or at least acquiesced to the creation of an underclass-clinical fellows, staff attorneys, visitors from practice-who now carry a significant share of actual student supervision, without job security or any role in law school governance. Moreover, they have been unable to stem the trend in tenure-track hiring that privileges advanced degrees and fellowship-driven scholarship over significant practice experience.

Second, the poverty law foundation of clinical education, and its emphasis on values-local community empowerment, social justice and law reform - has been eroded. If experiential learning is going to appeal to the current generation of law students, it must address their career aspirations. ${ }^{2}$ New clinics do not handle poverty law concerns such as landlord-tenant matters, but entrepreneurship, intellectual property, arts law and other glamourous appearing legal endeavors; externships with for-profit law firms and corporations are the norm. ${ }^{3}$ Thus, clinical education has come to reify the established hierarchy of law practice, with legal services for poor people at the bottom.

Where does the Clinical Law Review (CLR) fit into all this, as we celebrate the 25th anniversary of its founding with this symposium issue? It most certainly falls within "the best" category. It has given voice to every aspect of experiential education: from clinical program design, to pedagogical innovation, to exploration of narrative theory, to investigation of lawyering competencies, to examination of cultural competencies. It is a "must read" for all clinical teachers. Whenever someone asks me about entering the clinical teaching world, the first thing I say is, "Go read the Clinical Law Review."

From a more instrumental perspective, it has given countless new teachers the credentials to begin to move up the academic ladder, from fellowships and staff attorney positions to those with some form of job security. And through the peer editing process, it has advanced the quality of clinical scholarship immeasurably.

But again, there is another side to the story. In some sense, the CLR has created a silo for clinical scholarship. In the last 25 years, it seems that there has been little infiltration of clinical scholarship into

2 See, e.g., Praveen Kosuri, Clinical Legal Education at a Generational Crossroads: $X$ Marks the Spot, 17 CLIN. L. REv. 205, 208 (2010) (law students "want someone to show them what it means to be a lawyer, not just a public interest lawyer"); Stephen F. Reed, Clinical Legal Education at a Generational Crossroads: A Self-Focused Self-Study of Self, 17 CLIN. L. Rev. 243, 250 (2010) (the "larger constituency [of law students] wants to learn practical skills that will help them to become Great BigLaw Lawyers, not Great Public Interest Lawyers").

3 See Bernadette T. Feeley, Guiding Law Students through For-Profit Field Placements, 19 Clin. L. Rev. 57 (2012). 
flagship law reviews, as "elite" legal scholarship has become allegedly more "theoretical," empirical, interdisciplinary, and less grounded in practice. ${ }^{4}$ While the CLR is a haven for clinical scholarship, we should not let it become a ghetto. It is tempting to send our clinical writing only to the CLR - where we know it will find a receptive audience-rather than go through the general submission process. But it may be worthwhile to try to spread the word a bit more widely.

But to return to the theme of this essay, it proceeds in four parts. The first briefly looks at the history of clinical legal education to give context to more recent developments. Part two considers the "crisis" in legal education precipitated by the economic downturn beginning in 2008. Parts three and four address the ramifications of that crisis and its impact on both who teaches and what is taught in today's clinics. In the final part, I suggest that it is time to reexamine the core foundations of clinical education, specifically to insure that we are staffing clinics in a manner that respects the career aspirations of our junior colleagues and that we are instilling in our students the social justice values that have been our bulwark. This essay concludes with some recommendations for counteracting "the worst," while capitalizing on "the best."

\section{Clinical Education in Historical Context}

The beginnings of clinical education in the 1960s grew out of law students' growing political involvement and desire for a more relevant experience. ${ }^{5}$ Spurred by the civil rights movement, young people flocked to law school hoping to work for social change and were discouraged to find a calcified curriculum having little to do with their aspirations. Law school faculties also felt the need for change.

At the same time, as part of President Johnson's "war on poverty," federally funded civil legal services offices were first established. These fledging enterprises, staffed by idealistic and

4 I attempted an unscientific survey of where clinical teachers publish their scholarship by reviewing the last five years of CLEA newsletters, where new writing is regularly selfreported. See Clinical Legal Education Association Newsletters, https://clea.wildapricot. org/newsletters. Of the over 500 pieces, under a dozen appeared in top 50 law school flagship journals, and only one in a top six review, whose authors were in fact not clinical teachers. Of course, law review placement is in no way an accurate measure of scholarship quality, but unfortunately, to some degree, it does reflect how clinical scholarship is perceived by law review editors. Or it may be that clinical faculty are simply not submitting to these journals.

5 The history of the clinical legal education movement has been chronicled by me and, in much more detail, many others. See, e.g., Peter A. Joy, The Uneasy History of Experiential Education in U.S. Law Schools, 122 Dick. L. Rev. 551 (2018); Minna J. Kotkin, Reconsidering Role Assumption in Clinical Education, 19 N.M. L. Rev. 185 (1989). The following section is just a brief and somewhat impressionistic precis of the subject. 
overworked young lawyers, began to look to law students as a means of leveraging their impact. Clinical education began with students volunteering at local legal services offices, where they were thrown into the thick of poverty law practice without much guidance from the only marginally more experienced staff attorneys. Nevertheless, many politically minded students were thrilled with the opportunity to get out of the stuffy law school environment and help real clients.

These informal relationships were transformed by the efforts of the Ford Foundation's Council on Legal Education and Professional Responsibility (CLEPR), founded in 1968, which had as its dual goals to increase the availability of free legal services and to raise the academic community's awareness of the need for services. ${ }^{6}$ CLEPR provided substantial seed money for law schools to establish their own legal services offices. The law schools turned to the obvious source of staffing, legal services lawyers, who largely replicated their high volume, low supervision model. Thus began the first in-house clinics, often in the literal or figurative basements of law school buildings.

Once in the academy, however, the former legal services lawyers, usually titled "staff attorneys," went through a transformation in the 1970s. They began to adopt the values of the academy, moving from an emphasis on lawyering to teaching. And they became conscious of the huge disparity in status and pay compared to the traditional faculty. The greater emphasis on teaching made it necessary to significantly decrease caseloads, as well as student-supervisor ratios, and to develop theories of lawyering that could be articulated and taught rather than just observed. The resulting scholarship on lawyering gave clinical teachers more legitimacy in the academy and bolstered their argument for pay and status parity. Staff attorneys became "instructors" and still later professors.

As a core group of clinical teachers achieved professorial status, and eventually tenure in the 1980 s, they began a more concerted effort to fully integrate their clinical colleagues across the country into the academy, by making them all eligible for tenure or an equivalent form of job security. Their underlying goal, however, was not rooted solely in status issues but in educational reform: to move legal education towards a fully experiential model infused with social justice values. This effort culminated in 1984 with the adoption of the American Bar Association Accreditation Standard 405(e), which provided that in order to obtain or continue its accreditation, a law school "should afford to full-time faculty whose primary responsibilities are in its pro-

${ }^{6}$ For a full discussion of CLEPR's impact, see J.P. "Sandy" Ogilvy, Celebrating CLEPR's 40th Anniversary: The Early Development of the Clinical Legal Education and Legal Ethics Instruction in U.S. Law Schools, 16 CLIN. L. REv. 1 (2009). 
fessional skills program a form of security of position reasonably similar to tenure and perquisites reasonably similar to those provided other full-time faculty." 7 The accompanying interpretations of the Standard noted that job security could be in the form of a separate tenure track or a renewable long-term contract, but gave law schools a sizeable escape hatch by permitting "a limited number of fixed shortterm appointments in a professional skills program predominantly staffed by full-time faculty members." Another interpretation was added in 1988, ensuring that clinical faculty would be accorded a similar opportunity to participate in law school governance as other full-time faculty. ${ }^{8}$ Finally, after years of lobbying by the clinical community, and the collection of evidence that many law schools were not in compliance with 405(e), the language of the standard, now 405(c), was changed in 1997 from "should" to "shall," in an effort to give some teeth to accreditation review. ${ }^{9} \mathrm{~A}$ final significant regulatory action occurred in 2005 when an interpretation was issued making clear that a long-term contract must be for at least five years and must be presumptively renewable. ${ }^{10}$

During this entire pre-recession period, there was slow but steady progress in the clinical arena. In those times of plenty, clinical programs expanded substantially, and by 2007, every law school offered at least one clinical course. ${ }^{11}$ Some law schools established a unitary tenure track, with equivalent scholarship requirements and complete governance participation, including voting on all appointment and promotion matters - the gold standard for parity. Many others took the "specialized tenure" or long-term contract route, which provided job security but typically did not permit voting on personnel matters outside of clinic appointments. ${ }^{12}$ With status came scholarship demands, leaving clinical teachers less time for student supervision and reinforcing the low student-faculty ratio and small case model.

\section{Recommendations and Recession}

Up until the time that legal services lawyers invaded the acad-

7 See Peter A. Joy \& Robert R. Kuehn, The Evolution of ABA Standards for Clinical Faculty, 75 TENN. L. Rev. 183, 190-206 (2008).

8 Id. at 207-08.

9 Id. at 210-13. See also Peter A. Joy, ABA Standard 405(c): Two Steps Forward and One Step Back for Legal Education, 66 J. LEGAL ED. 606 (2017).

10 Joy \& Kuehn, The Evolution of ABA Standards for Clinical Faculty, supra note 7, at 220-223.

11 Bryan L. Adamson et al., The Status of Clinical Faculty in the Legal Academy: Report of the Task Force on the Status of Clinicians and the Legal Academy, 36 J. Legal Prof. 353 (2012) [hereinafter "Task Force Report"].

12 For a full discussion of five models of clinical faculty status, see id. at 372-379. 
emy, legal education remained static for decades, with Langdell's nineteenth century case method firmly entrenched throughout the three years. Although occasional criticisms were voiced in the 1930s, the first major modern inroad dates from the 1979 ABA study known as the Cramton Report. ${ }^{13}$ It challenged the case method beyond the first year, recommending that law schools "address the durable and fundamental aspects of lawyer competence" and provide opportunities for oral and written communication with realistic exposure to the integrated demands of practicing law, primarily by means of small class simulation experiences. ${ }^{14}$ The Cramton Report may have resulted in some curricular additions, but it came and went with little significant impact.

Similar but more far-reaching reforms were proposed by the 1992 MacCrate Report, which argued that the case method not only failed to teach lawyering skills but emphasized "qualities that have little to do with justice, fairness, and morality in daily practice." 15 The report was largely viewed as a call for the expansion of clinical education with a focus on poverty law. It speaks at length about law school's obligation to instill social justice values as well as skills. It was widely discussed within the academy, with many schools organizing MacCrate task forces and committees. But the change was incremental and measured. And there was a mounting backlash, with the deans of over 100 schools organizing against the call for more skills education and improved status for clinical teachers. ${ }^{16}$

Another major call for reform came with a 2007 Carnegie Foundation report entitled "Educating Lawyers." 17 This report gave credit to the case method as a first-year methodology but was highly critical of the upper-class curriculum. It urged the adoption of a tiered pro-

13 Section on Legal Educ. And Admissions To The Bar, Am. Bar Ass'n, RePORT AND ReCOMmENdations of the TASK Force on Lawyer COMPETENCY: The ROLE OF THE LAW SCHOOLS (1979).

14 Id. at 1, 3-4.

15 ABA Section of Legal Education and Admissions to the Bar, Legal EduCation and Professional Development - An Educational Continuum (Report of the Task Force on Law Schools and the Profession: Narrowing the Gap) 236 (1992).

16 The American Law Deans Association ("ALDA") was organized largely to oppose ABA regulation of the status of skills teachers. See Ann Bartow, American Law Deans Association (ALDA) Attacks Tenure and Long Term Contracts; ABA Standards $\S \S 205(c)$, 405, and 603(d), Feminist Law Professors Blog (Mar. 6, 2006) http://www.feministlawprofessors.com/2006/03/american-law-deans-association-alda-attack-tenure-and-long-termcontracts-aba-standards-\%C2\%A7\%C2\%A7-205c-405-and-603d/. See also Joy \& Kuehn, supra note 7 , at 213-219.

17 William M. Sullivan, Anne Colby, Judith Welch Wegner, Lloyd Bond \& Lee S. Shulman, Educating Lawyers: Preparation for the Profession of Law (Carnegie Foundation for the Advancement of Teaching 2007). 
gression through the three years, from doctrine to skills to professional role assumption. Again, it precipitated much discussion and consideration but no rapid movement.

Then came the recession of 2008, which most experts believe has changed the legal profession for good. It has had a far-reaching effect on legal education, well beyond that of various reports and committee efforts. ${ }^{18}$ To summarize briefly, when the economy collapsed, the large law firms were hit hard: between 2009 and 2011, the number of associates hired out of law school dropped from 5200 to $2900 .{ }^{19}$ The trickle-down effect pushed students into smaller firms and left those in less competitive positions without jobs at all. With significantly fewer high-paying jobs available, tuition continuing to rise sharply, and bad publicity about the value of law school coming out almost daily, the number of law school applicants declined precipitously: from 96,000 in 2006 to 56,000 in 2016.20 Despite the recovering economy, the bestqualified potential applicants remain on the sidelines, with only a small uptick in applications. ${ }^{21}$

Faced with these economic realities, law schools finally embraced experiential learning for real, heeding the virtually unanimous call of the bench, the bar, and students to produce more "practice-ready" graduates. This is the "good." Law schools across the country now bill themselves as centers of clinical excellence, and regularly tout their expanding programs.

There are, of course, countervailing considerations of cost, however. With shrinking tuition dollars available, law schools were looking for ways to run clinics on the cheap. This brings us to my first concern with the replication of hierarchy.

\section{The Replication of Hierarchy Through Hiring Trends}

As discussed above, clinical teachers fought a long battle to move from staff attorneys to professors with job security. With the growth of experiential offerings, one would expect to see an expansion in the

18 For a full discussion of the effect of the recession, see Peter A. Joy, Challenges to Legal Education, Clinical Legal Education, And Clinical Scholarship, 26 CLIN. L. REV. 237 (2019).

19 William M. Treanor, The Crisis in Legal Education, American Academy of Arts \& Sciences Spring 2016 Bulletin, https://www.amacad.org/news/crisis-legal-education.

20 Id.

21 There is some evidence that the recent increase in applications is the result of the socalled “Trump bump." See Paul Caron, 'Trump Bump' Continues to Fuel Law School Applications, TAXPROF BLOG (Mar. 11, 2019), https://taxprof.typepad.com/taxprof_blog/2019/ 03/trump-bump-continues-to-fuel-law-school-applications-html. See also Paul Caron, Testy: The Quantity and Quality of Law School Applicants: 2018 Edition, TAxProf BLOG (Sept. 7, 2018), https://taxprof.typepad.com/taxprof_blog/2018/09/testy-the-quantity-andquality-of-law-school-applicants-2018-edition.html. 
ranks of the clinical professoriate. Alternatively, law schools might go the path of creating a more integrated faculty, with newly hired professors willing and able to teach clinical and traditional courses or even melding the two together. Sadly, neither of these predictions have borne out. In this section, I will look at law school hiring patterns since the recession and their impact on clinical education.

\section{A. Traditional Hiring}

First, let's consider "traditional" tenure-track positions. With law school enrollment shrinking more than $20 \%$ in the last ten years, hiring has taken a hit: from a high of 167 in 2008 to a low of 62 entry level positions in 2017 , rebounding slightly to 82 in 2019.22 But what is significant for my thesis is the characteristics of those hired. In the olden days, the criteria for faculty positions were fairly set: a top-tier law degree; a law review editorship; a prestigious, preferably federal circuit or U.S. Supreme Court clerkship; and perhaps a few years at a big firm or an elite government agency. No longer are these meaningful benchmarks. Today, the "coin of the realm" is a fellowship and/or an advanced degree, particularly a Ph.D. Of the 2017 hires, $82 \%$ completed a fellowship, more than half of which were at five schools: Harvard, NYU, Georgetown, Penn and Columbia, as compared to $42 \%$ ten years ago. Forty-two out of 62 hires held an advanced degree, of which 26 or $42 \%$ were doctorate level, as compared to $10 \%$ in 2000 hires. Only 32 out of 62 had clerkships, however. ${ }^{23}$

A recent empirical study by Lynn LoPucki looks at the increase in Ph.D.'s on law school faculties and its meaning for legal education. ${ }^{24} \mathrm{He}$ found that:

J.D.-only professors hired from 2011 through 2015 were twice as likely as the J.D.-Ph.D.s to have practiced law ( $86 \%$, as compared with $43 \%$ ) and practiced an average of four times as long (3.6 years, as compared with 0.9 years). Seventy-seven percent of the J.D.-only professors clerked, as compared with only $50 \%$ of the J.D.-Ph.D.s, and the J.D.-only professors clerked an average of 1.2 years, as compared with 0.7 years for the J.D.-Ph.D.s.

The gap with respect to elite clerkships also widened. Among the 2011-15 hires, $29 \%$ of the J.D.-only professors clerked for the

22 Sarah Lawsky, Spring Self-Reported Entry Level Hiring Report 2019, PrawfsBlawg (June 8, 2019), https://prawfsblawg.blogs.com/prawfsblawg/entry-level-hiring-report/.

23 Sarah Lawsky, Spring Self-Reported Entry Level Hiring Report 2017, PrawFsBlawg (June 1, 2017), https://prawfsblawg.blogs.com/prawfsblawg/2017/06/spring-self-reported-entry-level-hiring-report-2017.html.

24 Lynn M. LoPucki, Dawn of the Discipline-based Law Faculty, 65 J. Legal Educ. 506 (2016). 
United States Supreme Court, as compared with only $2 \%$ of the J.D.-Ph.D.s. $77 \%$ of the J.D.-only professors clerked for United States Courts of Appeals, as compared with only $44 \%$ of the J.D.Ph.D.s. ${ }^{25}$

LoPucki notes that these trends will continue and in fact accelerate, as faculties tend to "hire in their own image." He estimates that in ten years, half of all faculty members will have Ph.D.s, and little to no practice experience, and concludes that:

Individual faculty members have long grappled with the difficulties of preparing students to practice a profession they have not themselves practiced. They have done so with the benefit of colleagues who have practiced. But as the decline in legal experience on law faculties accelerates, the discipline-based law faculty members will be increasingly on their own. ${ }^{26}$

LoPucki also documented the decline in practice experience at the top 26 law schools, finding that in 2015, the average was 1.5 years, declining since 2010 from close to 3.5 years, as shown in the following graph. ${ }^{27}$
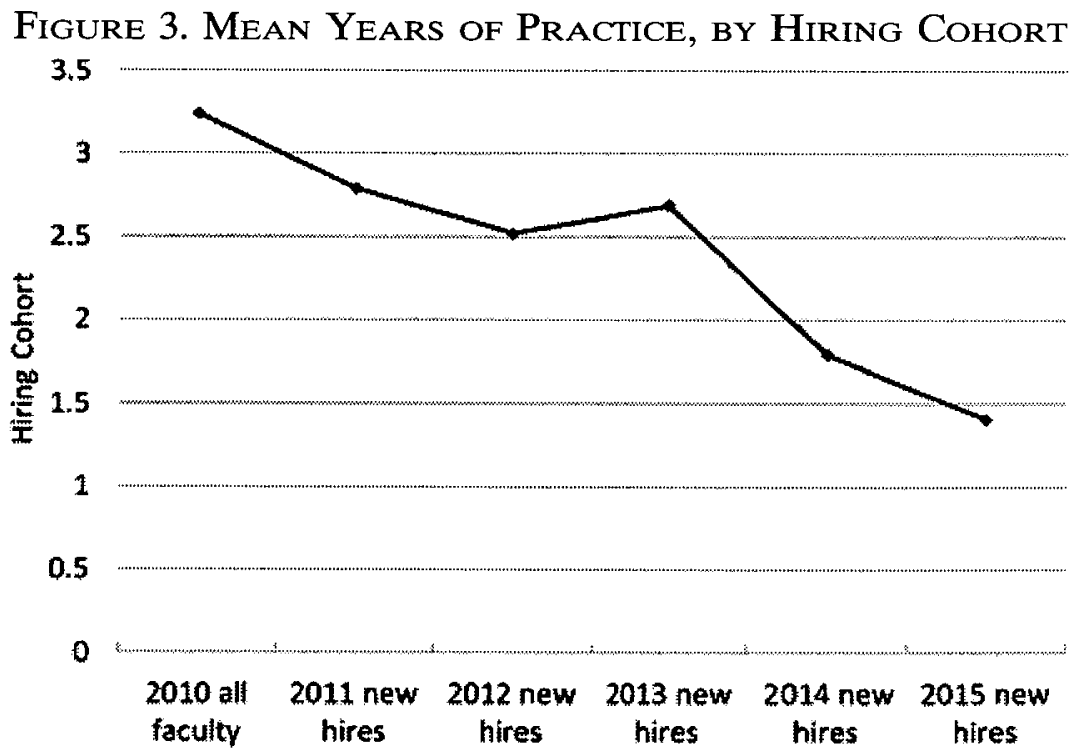

Sarah Lawsky's excellent analysis of entry level hiring more than bears out LoPucki's predictions. ${ }^{28}$ Over a number of years, she has tracked the number of entry level tenure-track hires who self-report

\footnotetext{
$25 I d$. at 508.

26 Id. at 541.

27 Id. at 523.

28 Sarah Lawsky, supra note 22.
} 
whether they have had clerkships, fellowship, or higher degrees. For 2019 , she found that, "Every reported hire had a least one of these credentials." 29 Since 2011, the percentage of those with doctorates has risen from $27 \%$ to $53 \%$. 30 The following chart indicates that $96 \%$ of hires have either completed a Ph.D. or a fellowship. ${ }^{31}$

DOCTRINAL

FEllowship AND/OR Doctorate

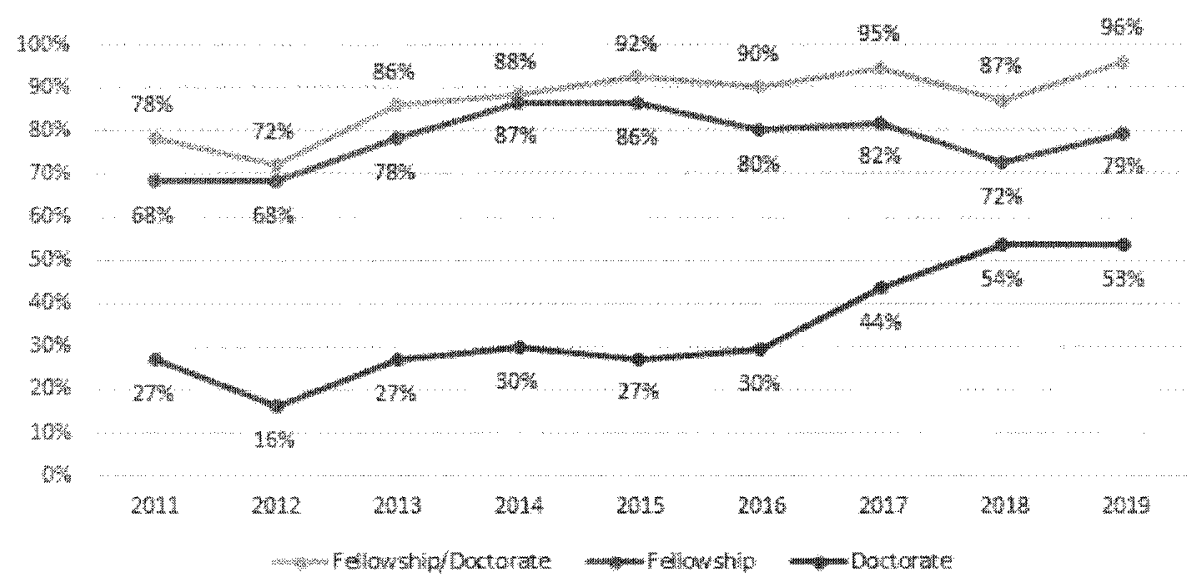

Thus, it seems clear that the expansion of experiential learning will not be addressed by reliance on the faculty at large, since fewer and fewer will arrive with any practical experience. But there are even larger risks at stake. With the movement toward tenure availability and scholarship requirements, clinical faculty began to gain a seat at the table. Traditional teachers were more likely to view clinicians as full members of the academy. The movement towards what LoPucki calls the "discipline-based faculty" is one that devalues practice and practical scholarship and may well end up devaluing clinics and clinical teachers. It may be that status issues have taken on the qualities of a pendulum that is now swinging back, as the next section suggests. 


\section{B. Clinical Faculty}

As experiential education has grown in importance, one might expect an increase in the raw numbers of clinical teachers and in their progression within the faculty hierarchy. While the number of teachers has increased substantially, ${ }^{32}$ the available statistics show that their position in the academy has not progressed as would be expected. In fact, it appears that there has been a steady erosion in the status of clinical teachers, the result of which is that they have less influence in the trajectory of their schools and in legal education in general.

Since 2007, the Center for the Study of Applied Legal Education (CSALE) has collected data on clinical education every few years through a sophisticated survey mechanism. In the latest survey, 2016$2017,94 \%$ of ABA accredited law school responded, including over 1000 individual clinical teachers. ${ }^{33}$ In this section, I rely on the CSALE data comparing the status of clinical teachers over the years as reported by three surveys: 2010-11, 2013-14 and 2016-17.

At the outset, it is noteworthy that there has been a steady decline in the percentage of clinical teachers who are employed on a fulltime basis: $82 \%$ in $2010-11 ; 78 \%, 2010-11$; and $72 \%, 2016-17 .{ }^{34}$ It is unclear whether these numbers refer to adjunct instructors or actual part-time faculty members, but in either case, it is fair to say that parttimers will not play a significant institutional role at their schools.

The table below shows the status of full-time instructors over the three survey periods. ${ }^{35}$

32 It is surprisingly difficult to find a count of clinical teachers. The AALS Directory of Law Teachers lists over 2000 faculty members as currently teaching in clinics. The 2012 Task Force Report estimated the number at 1400. See Task Force Report, supra note 11, at 372.

33 Robert R. Kuehn \& David Santacroce, The 2016-17 Survey of Applied Legal Education (July 2019), https://ssrn.com/abstract=3397322 [hereinafter CSALE 2016-17].

34 Id. at 15.

35 Id. at 41. 


\begin{tabular}{|l|c|c|c|}
\hline \multirow{2}{*}{$\begin{array}{c}\text { Employment Status - } \\
\text { All Full-Time Instructors }\end{array}$} & \multicolumn{3}{c|}{ Percentage Reporting } \\
\cline { 2 - 4 } & $\mathbf{2 0 1 0 - 1 1}$ & $\mathbf{2 0 1 3 - 1 4}$ & $\mathbf{2 0 1 6 - 1 7}$ \\
\hline Tenured & 24 & 21 & 18 \\
\hline Tenure Track & 7 & 4 & 7 \\
\hline Clinical Tenured & 6 & 5 & 7 \\
\hline Clinical Tenure Track & 3 & 3 & 3 \\
\hline 5 year (or more) Contract & 20 & 22 & 25 \\
\hline 4 year Contract & $<1$ & $<1$ & $<1$ \\
\hline 3 year Contract & 10 & 9 & 12 \\
\hline 2 year Contract & 3 & 5 & 4 \\
\hline 1 year Contract & 13 & 13 & 12 \\
\hline Adjunct & 2 & 9 & 2 \\
\hline Fellow & 4 & 4 & 3 \\
\hline Non-Adjunct At Will Employee & 3 & 3 & - \\
\hline Administrative position w/ faculty title & - & - & 3 \\
\hline Administrative position w/out faculty title & - & - & 2 \\
\hline Other & 5 & 3 & 4 \\
\hline
\end{tabular}

The data regarding the status of teachers who are "in charge of a clinic (i.e. the director)" reveals the same pattern. These figures run even more counter to expectations, since it would be presumed that clinic directors would have more status than clinical teachers in general. ${ }^{37}$

36 "Percentage Reporting," here and in the next charts, refers to the percentage of all teachers responding to the survey who chose each category.

.37 Id. at 21 . 


\begin{tabular}{|l|c|c|c|}
\hline \multirow{2}{*}{\begin{tabular}{l} 
Job Description \\
\cline { 2 - 4 }
\end{tabular}} & \multicolumn{3}{c|}{ Percentage Reporting } \\
\hline Tenured & $\mathbf{2 0 1 0 - 1 1}$ & $\mathbf{2 0 1 3 - 1 4}$ & $\mathbf{2 0 1 6 - 1 7}$ \\
\hline Tenure Track & 23 & 25 & 20 \\
\hline Clinical Tenured & 7 & 7 & 6 \\
\hline Clinical Tenure Track & 8 & 8 & 9 \\
\hline 5 Year (or more) Contract & 5 & 4 & 4 \\
\hline 4 Year Contract & 19 & 18 & 22 \\
\hline 3 Year Contract & 2 & $<1$ & $<1$ \\
\hline 2 Year Contract & 8 & 10 & 8 \\
\hline 1 Year Contract & 3 & 2 & 2 \\
\hline Adjunct & 9 & 9 & 10 \\
\hline Fellow & 9 & 13 & 13 \\
\hline Non-Adjunct At Will Employee & - & $<1$ & 0 \\
\hline Other Employment Terms & 8 & 1 & $<1$ \\
\hline
\end{tabular}

What this data suggests is a steady decline in tenure and tenuretrack positions, with a concomitant increase in long-term contract positions. There is, of course, something to be said for the job security provided by contract positions for the individuals involved, but this bifurcation of status between clinical and doctrinal teachers only serves to cement the hierarchical division of legal education. Instead of closing the theory-practice dichotomy, we are moving further apart.

Further evidence of the entrenchment of hierarchy is CSALE's data on voting rights. The primary distinction between tenure/tenure track and long-term contract positions relates to this issue. Tenure status brings with it full voting rights, while long-term contract holders are typically excluded from voting on faculty hiring, promotion and tenure matters. A 2012 study found that only $15 \%$ of these long-term contract clinical faculty have voting rights on all matters of faculty governance. Sixty-nine percent are permitted to vote on all matters except the hiring and promotion of doctrinal faculty. Five percent are permitted to vote on administrative matters only and $11 \%$ are not permitted to vote on anything, although they can attend faculty meetings. ${ }^{38}$

The most recent CSALE data does not break down voting rights by status, but it does show a significant decline in those clinical teachers entitled to vote on all matters: ${ }^{39}$

\footnotetext{
38 Task Force Report, supra note 11, at 376.

39 CSALE 2016-17, supra note 33, at 45.
} 


\begin{tabular}{|l|c|c|c|}
\hline \multirow{2}{*}{ Matters To Be Voted On } & \multicolumn{3}{|c|}{$\begin{array}{c}\text { Percentage of Respondents } \\
\text { Entifled to Vote }\end{array}$} \\
\cline { 2 - 4 } & $\mathbf{2 0 1 0 - 1 1}$ & $\mathbf{2 0 1 3 - 1 4}$ & $\mathbf{2 0 1 6 - 1 7}$ \\
\hline All Matters & 37 & 33 & 29 \\
\hline $\begin{array}{l}\text { All Except Classroom/Doctrinal } \\
\text { Faculty Hiring, Promotion and } \\
\text { Tenure }\end{array}$ & 31 & 36 & - \\
\hline $\begin{array}{l}\text { All Except Classroom/Doctrinal } \\
\text { Faculty Hiring }\end{array}$ & - & - & 13 \\
\hline $\begin{array}{l}\text { All Except Classroom/Doctrinal } \\
\text { Faculty Promotion and Tenure }\end{array}$ & & - & 33 \\
\hline $\begin{array}{l}\text { Not Vote But Can Generally Attend } \\
\text { Meetings }\end{array}$ & 19 & 23 & 16 \\
\hline $\begin{array}{l}\text { Not Permitted to Attend Faculty } \\
\text { Meetings }\end{array}$ & 12 & 7 & 4 \\
\hline Administrative Matters Only & 1 & 2 & 5 \\
\hline
\end{tabular}

These trends run directly counter to the recommendations of the Association of American Law Schools 2012 Task Force Report on the Status of Clinicians and the Legal Academy. ${ }^{40}$ In addressing the issue of hierarchy, the report clearly puts forward the harm caused by limiting the voting rights of clinical faculty.

No decisions are as important to the mission, function, and direction of law schools as decisions about hiring, retention, and promotion of law school faculty members. Hiring, retention, and promotion decisions reflect the priorities of a law school through its allocation of resources. Such decisions also shape a law school's identity and constitute the body of faculty members who will govern other important decisions affecting the law school. To exclude clinical faculty members from hiring, retention, and promotion decisions disenfranchises them in ways that have deep and longstanding effects on the shape and direction of a law school program. A vision of equal governance cannot exclude clinical faculty members as a class from faculty governance on those critical judgments. ...

In excluding clinical faculty from full governance over issues involving the mission and direction of law schools, especially faculty hiring, retention, and promotion, law schools have created hierarchies in which one class of permanent faculty members makes decisions affecting another class of permanent members, often without reciprocity. Such hierarchies exist without reasonable and adequate 
justification. ${ }^{41}$

The Task's Force most significant recommendation was that traditional tenure status should be extended "to full-time clinical faculty or at minimum, to a predominant core of well-qualified full-time clinical faculty."42 It appears, however, that legal education is moving in the opposite direction.

While the CSALE data is highly informative, my anecdotal impression is that it does not give a full picture of how far the clinical teaching job market has shifted to short-term positions. To test that impression, I reviewed a year's worth of job announcements posted on the CLEA website, where it is fair to assume that close to $100 \%$ of openings appear. Of the 90 jobs advertised from July 2018 to July 2019 , only 12 , or $13 \%$, specified that the position was tenure eligible, and Georgetown accounted for four of those positions. ${ }^{43}$ Another dozen or so mentioned the availability of long-term contracts, but approximately $75 \%$ of the positions were for fellowships, staff attorneys, visitors, or non-faculty "directors."

Given this data, it appears that the growth of experiential education has not led to an equivalent integration of clinical teachers into the faculty mainstream. We see fewer tenured clinicians, and at least anecdotally, a huge increase in short-term positions without any form of job security. At the same time, the doctrinal faculty is increasingly divorced from practice and oriented towards what Judge Harry Edwards famously criticized in 1992 as writing that "emphasiz[es] abstract theory at the expense of practical scholarship and pedagogy." 44

\section{The Replication of Hierarchy in Clinical Subject Matter}

Not only have hierarchies come to dominate the staffing of clinical programs, but hierarchies have invaded their subject matter as well. The original clinical model grew out of a poverty law-based legal services practice and typically involved landlord-tenant, public benefits and family law matters. Progressive lawyers flocked to legal services offices in the 1970s, and imported their caseloads to clinics in the 1980s.

In terms of traditional legal practice hierarchies, poverty law has

41 Id. at $382-383$.

42 Id. at 356.

43 See Clinical Legal Education Association, Jobs, https:/www.cleaweb.org/Jobs. A shout out to the other law schools advertising tenure-track jobs to teach in clinic: Albany, CUNY, Drake, John Marshall, North Carolina, South Carolina, Tennessee and Utah.

44 Harry T. Edwards, The Growing Disjunction Between Legal Education and the Legal Profession, 91 Mich. L. REv. 34, 34 (1992). 
always been at the bottom of the ladder. The well-known 1970s study of the Chicago bar found "two hemispheres" of practice: those who represented individuals and the elite, who represented business entities. ${ }^{45}$ Until the advent of publicly funded legal services, poor people did not even figure into this calculus, as they had virtually no access to legal services. Part of the goal of legal services and clinical programs was to equalize the resources available to poor people.

Nor are these sorts of hierarchies limited to the private bar. As Rebecca Sharpless has cogently noted, "[p]rogressive legal scholars and practitioners have created a hierarchy within social justice lawyering. Direct service attorneys-non-profit attorneys who focus on helping individuals in civil cases-sit at the bottom." 46 Sharpless chronicles the history of the movement away from direct services in detail, discussing how critical theory and notions of rebellious lawyering contributed to the creation of what she calls a "hierarchy of helping." 47

Today, the classic legal services style practice no longer is the most prominent feature of the clinical world. Instead, programs that replicate the more elite elements of private and public practice have proliferated. Here again, the CSALE data is informative. ${ }^{48}$ From 2007-08 to 2016-2017, the percentage of schools offering a general civil clinic has decreased from $43 \%$ to $36 \%$, the largest drop in any subject area. Housing clinics dropped from $21 \%$ in $2013-14$ to $16 \%$ in 2016 17.49

In 2007-2008, no schools reported having a clinic with a substantive focus of "entrepreneur/start-up/small business." In 2016-2017, $29 \%$ of schools had such an offering. Intellectual property clinics rose from $11 \%$ to $23 \% .50$ These two subject areas represent the largest

45 See John P. Heinz \& Edward O. Laumann, Chicago Lawyers: The Social Structure of THE Bar (1982); John P. Heinz et al., The Changing Character of Lawyers Work: Chicago in 1975 and 1995, 32 LAW \& Soc'y Rev. 751 (1998); see also Bryant G. Garth \& Joyce S. Sterling, Diversity, Hierarchy, and Fit in Legal Careers: Insights from Fifteen Years of Qualitative Interviews, 31 Geo. J. LEGAL ETHICs 123 (2018).

46 Rebecca Sharpless, More Than One Lane Wide: Against Hierarchies of Helping in Progressive Legal Advocacy, 19 CLIN. L. REv. 347, 347 (2012). This sort of hierarchy pervades the "traditional" legal academy as well. Many scholars have noted that those who teach subjects like family law and trusts and estates, often women, are accorded less status and influence in the academy. See, e.g., Deborah Jones Merritt \& Barbara F. Reskin, Sex, Race, and Credentials: The Truth about Affirmative Action in Law Faculty Hiring, 97 Colum. L. Rev. 199, 259-275 (1997).

47 Id. at $376-81$.

48 Compare David A. Santacroce \& Robert R. Kuehn, Report on the 2007-2008 Survey, (Center for the Study of Applied Legal Education 2009), http://www.csale.org/files/ CSALE.07-08.Survey.Report.pdf with CSALE 2016-2017, supra note 33.

49 Id.

$50 \mathrm{Id}$. 
growth in clinical programs by far. In a more general categorization, a 2012 study found that there were more than 140 transactional clinics at the 200 ABA-approved law schools. ${ }^{51}$

In Paul Tremblay's contribution to this issue, he notes the growth of articles about business or transactional subjects: only one such article appeared in the first six years of the CLR, as compared to 13 in the last six years. ${ }^{52}$ This change is not surprising; the burgeoning scholarship reflects the change in the composition of clinical programs. But Tremblay points out the distinction between transactional clinics grounded in community lawyering principles, and those with a pure business focus:

[C]ommunity lawyering is but a small segment of the transactional practice universe. The constant underlying premise of community lawyering is a notion of the neighborhood, the group, or the collective, as the lawyer's client. Sometimes that will be true for small business lawyers, but usually not. More commonly, the clients of a small business practice are founders or owners of beginning enterprises, and the lawyer's commitment is to the success, and indeed the private success, of those enterprises. That aim is seldom a notable priority within the community lawyering literature.

If one separates out the transactional themes of the community lawyering literature, the contrast between the early years of the Clinical Law Review and the more recent publication record is more stark. The early years evidenced very little attention to small businesses, startups, entrepreneurship, and intellectual property, while the more recent issues offer greater coverage of those subjects. ${ }^{53}$

I do not want to dwell here on the debate about whether these new business-oriented clinical subjects, excluding those grounded in community lawyering, represent a complete departure from the social justice mission of clinical education. A number of clinical scholars have mounted vigorous defenses of their social utility, claiming that they serve to inculcate the traditional clinical values of promoting justice and equality for the under-represented. ${ }^{54}$ They argue, as Tremblay describes, that "assistance to low-wealth entrepreneurs, particularly

51 Susan R. Jones and Jacqueline Lainez, Enriching the Law School Curriculum: The Rise of Transactional Legal Clinics in U.S. Law Schools, 43 WASH. U. J. L. \& POL'Y 85 (2014).

52 Paul R. Tremblay, The Emergence and Influence of Transactional Practice Within Clinical Scholarship, 26 CLIN. L. REv. 375, 378 (2019).

53 Id. at 380.

54 See, e.g., Lynnise E. Pantin. The Economic Justice Imperative for Transactional Law Clinics, 62 Vill. L. Rev. 175 (2017); Joseph Pileri, Expanding Our Reach: Direct Client Representation vs. Policy and Advocacy Impact in a Transactional Clinic, 26 J. AfFordABLe Housing 325 (2017). 
those from disadvantaged communities and entrepreneurs of color, will have a meaningful effect on the development of financial and social capital with those communities and among those participants." 55 I do not take issue with those arguments. I only posit here that the proliferation of these programs, and their availability and desirability to law students replicates the hierarchy of the legal profession in general, and we should be alert to guard against the entrenchment of that hierarchy.

Transactional law, particularly that involving entrepreneurs, has been deemed "happy law." 56 It avoids the conflict and the win-lose dynamic inherent in litigation settings. It does not invoke the struggle for justice and fairness that permeates poverty law. As a general matter, it does not create a learning environment where empathy and cultural awareness are daily concerns. I suggest that these values and skills should not be forgotten, in the three short years that we have the attention of future lawyers, as clinical education evolves.

\section{Conclusion}

This essay has addressed two forms of hierarchy that have infiltrated clinical legal education without much attention: the stratification of the clinical professoriate into haves and have nots, and the demand for and expansion of business-oriented clinics with questionable social utility that replicate the hierarchy of practice.

What is to be done, if anything? As to staffing, it seems unlikely that we can entirely turn back the clock entirely. Nevertheless, the clinical community should continue to advocate for unitary tenuretrack appointments and for the enforcement of Standard 405(c), which permits only a limited number of short-term positions. But we also need to provide more support for the have-nots.

Many law schools that run clinical fellowship or "visitor from practice" programs advertise them as a gateway to permanent clinical teaching positions, with mentorship, time and support to pursue scholarly writing. They provide little hard information by which to evaluate their value in terms of career aspirations, however. Similarly, programs that seek directors or staff attorneys fail to describe the parameters of those positions. There is little transparency when it comes to what an applicant can expect.

55 Tremblay, supra note 52 , at 390 .

56 See Rebecca B. Rosenfeld, The Examined Externship Is Worth Doing: Critical SelfReflection and Externship Pedagogy, 21 Clin. L. REv. 127, 153 (2014) (an externship student reports, "Makes me feel like I'm working in happy law helping incorporate a nonprofit arts project"). 
In this regard, I have two recommendations. ${ }^{57}$ First, we should learn from our legal research and writing colleagues, who, through the auspices of the Legal Writing Institute, have developed a "Job Posting Disclosure Form" that must be included for any position advertised on its website or listserv. ${ }^{58}$ The disclosure includes the status of the position, with six categories ranging from tenure-track to year-to-year appointments; faculty voting rights; salary range; and number of students to be taught. The clinical equivalent might also include information about classroom teaching and summer responsibilities, as well as the specifics of scholarship support (i.e. research assistance, summer release time and conference attendance).

Second, these programs should disclose the career trajectories of past fellows or visitors. This has been an ongoing concern for applicants to traditional teaching fellowships as well..$^{59}$ A cursory review of the websites for some of the better-known clinical fellowships reveals almost no data. Yale's Cover Fellowship gives no information about past fellows; its Ludwig Fellowship lists the names of past holders but not their current positions. ${ }^{60}$ At Georgetown, with its dozen clinical fellowship programs, only the Center for Applied Legal Studies includes what appears to be a partial list of those past fellows who have obtained permanent academic positions. ${ }^{61}$

Clinical programs should instead follow the model of the University of Chicago's Bigelow Fellowship, which lists the job placement of

57 The Task Force Report, supra note 11, discusses the proliferation of fellowship programs and makes excellent recommendations about how they should be structured to help fellows enter the clinical teaching world on a secure basis. It notes the importance of mentoring, teaching case rounds, and support for scholarship. It also comments, "[c]ritically, care must be taken to avoid the exploitation of clinical fellows," who may have difficulty negotiating case handling and teaching boundaries. Id. at 413 . The recommendations here go to that issue and are in addition to those outlined in the Report.

58 See Legal Writing Institute, Employment Listings https://www.lwionline.org/resources/employment-listings (last visited July 19, 2019) ("The completed form must appear within the body of an E-mail posting about a [job], and the completed form must be included within the text of any file attachment.").

59 See Jessica Erickson, New Summer Series: Interviewing Fellowship and VAP Directors, PRawfsBlawg (May 17, 2019), https://prawfsblawg.blogs.com/prawfsblawg/2019/05/ new-summer-series-interviewing-fellowship-and-vap-directors.html ("while there is some information available on the tenure-track market, there is surprisingly little information about these programs. How do you get a fellowship? How does one fellowship differ from another in terms of mentoring, teaching and research time, and basic employment terms?").

60 See Yale Law School, Cover-Lowenstein Fellowship, http://aw.yale.edu/schell/fellow ships/clinical-fellowship (last visited July 19, 2019); Ludwig Fellowship, https://law.yale.edu/ studying-law-yale/clinical-and-experiential-learning/our-clinics/ludwig-center-communityeconomic-development/ludwig-fellowship. (last visited July 19, 2019).

61 See Georgetown Law, CALS Graduate Teaching Fellowships, https://www.law.ge orgetown.edu/experiential-learning/clinics/center-for-applied-legal-studies/cals-graduateteaching-fellowships/ (last visited July 19, 2019). 
every fellow since the inception of the program in 2001.62 If we are to avoid exploiting an underclass of clinical instructors without status or job security, full transparency in this regard is a must. At the very least, if we are to continue to depend on short-term labor to staff our clinical programs, we should ensure that they have the opportunity for real career advancement.

As to the creation of subject-matter hierarchy within clinical programs, again, we cannot turn back the clock to the time when poverty law was the norm. On the other hand, we should not forsake the values that have underpinned clinical education since its inception. All transactional clinics, particularly those serving entrepreneurs, should carefully evaluate potential clients according to criteria consistent with social justice values. For example, is the entrepreneurial venture contributing to an underserved community or otherwise forwarding a progressive goal? Is the client a member of an underserved group without access to other legal resources?

Representing a college-educated computer whiz who is developing a cool new app that turns your face into a cartoon image may make for a "happy" clinical experience, one that may be appealing to many of our students and in line with their career aspirations. But this is not what clinical education was designed to accomplish, nor should we squander our limited resources on these ventures.

62 See University of Chicago Law School, Apply to be a Harry A. Bigelow Teaching Fellow, https://www.law.uchicago.edu/bigelow/howtoapply (last visited July 19, 2019). 